\title{
Implementation of IADPSG screening guidelines for gestational diabetes in a district general hospital
}

\author{
Authors: R Bhatti ${ }^{1}$, R Khan ${ }^{2}$ S Howard ${ }^{2}$, K Ellis ${ }^{2}$
}

Consultant Endocrinologist, King's College Hospital, Dubai, UAE

Department of Obstetrics'2, Worthing Hospital, Western Sussex NHS Trust, UK

\begin{tabular}{l}
\multicolumn{1}{|c}{ Introduction } \\
\hline -Managing diabetes in pregnancy is \\
challenging for women with both pre- \\
gestational and gestational diabetes (GDM). \\
-GDM is associated with adverse foetal and \\
maternal outcomes. \\
-A retrospective audit in 2015 against NICE \\
(NG3) showed that $40 \%$ of patients had \\
delayed diagnosis of GDM.
\end{tabular}

\section{Materials and Methods}

International association of the diabetes and pregnancy study groups criteria (IADPSG) for the diagnosis of GDM was implemented in Worthing Hospital in June 2016.

-Retrospective audit

-June 2016-December 2016

-Data collected from electronic records

Medway Maternity ${ }^{\circledR}$

\section{Baseline Characteristics}

\begin{tabular}{|l|l|}
\hline Total no of patients & 123 \\
\hline Gestational Diabetes & $85 / 123$ \\
\hline Previous GDM & $38 / 123$ \\
\hline $\begin{array}{l}\text { Maternal Age } \\
\text { (Mean } \pm \text { SD) }\end{array}$ & $32 \pm 5.6$ \\
$\begin{array}{l}\text { BMl } \\
\text { (Mean } \pm \text { SD) }\end{array}$ & $29.4 \pm 7.6$ \\
\hline $\begin{array}{l}\text { Gestation at diagnosis } \\
\text { (Mean } \pm \text { SD) }\end{array}$ & $23 \pm 10$ weeks \\
\hline $\begin{array}{l}\text { Pharmacological } \\
\text { intervention } \\
\text { (Mean } \pm \text { SD) }\end{array}$ & $26 \pm 8$ weeks \\
\hline $\begin{array}{l}\text { Birth Weight } \\
\text { (Mean } \pm \text { SD) }\end{array}$ & $3300 \pm 593$ gm \\
\hline \multicolumn{1}{|l}{ Missed on NG3 } & Criteria (n=16) \\
\hline $\begin{array}{l}\text { Diagnosis of GDM } \\
\text { (Mean } \pm \text { SD) }\end{array}$ & $13.2 \pm 3.5$ weeks \\
\hline $\begin{array}{l}\text { Pharmacological } \\
\text { intervention (Mean SD) }\end{array}$ & $18.7 \pm 4.9$ weeks \\
\hline
\end{tabular}

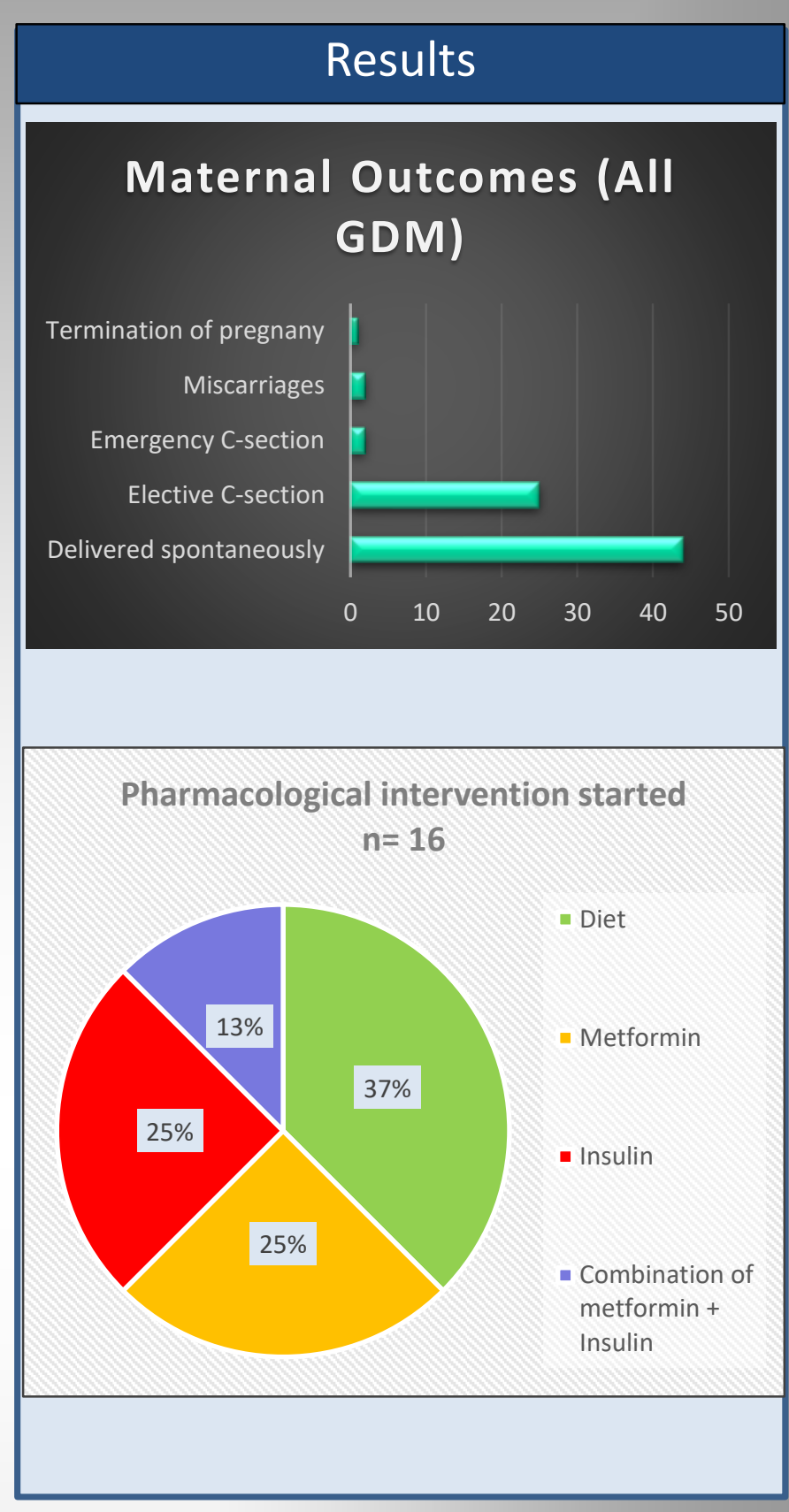

\section{Conclusions}

1-Implementation of IADPSG was associated with increase in early diagnosis of GDM.

(Mean 23 weeks of gestation)

2-16 patients would have been missed on NICE (NG3) criteria alone at booking ad further 11 patients missed at 28 weeks as not high risk.

3-Pharmacological intervention was required early in these patients. (Mean 18.7 weeks)

4-We aim to look at fetomaternal outcomes in 2017.

\section{References}

1 - International Association of Diabetes and Pregnancy Study Groups Consensus Panel, "International Association of Diabetes and Pregnancy study groups recommendations on the diagnosis and classification of hyperglycaemia in pregnancy," DiabetesCare,vol.33,no.3,pp.676-682,2010

2-Diabetes in pregnancy: management of diabetes and its complications from preconception to the 